Article

\title{
Candida albicans Adaptation on Simulated Human Body Fluids under Different $\mathrm{pH}$
}

\author{
Ana Barbosa ${ }^{\dagger}$, Daniela Araújo ${ }^{\dagger}$, Eduarda Ribeiro, Mariana Henriques(D) and Sónia Silva * \\ LIBRO—Laboratório de Investigação em Biofilmes Rosário Oliveira, CEB-Centre of Biological Engineering, \\ University of Minho, 4710-057 Braga, Portugal; pg38833@alunos.uminho.pt (A.B.); \\ danieira.araujo@gmail.com (D.A.); eduardaprr@gmail.com (E.R.); mcrh@deb.uminho.pt (M.H.) \\ * Correspondence: soniasilva@deb.uminho.pt \\ † Ana Barbosa and Daniela Araújo contributed equally.
}

Received: 14 January 2020; Accepted: 1 April 2020; Published: 3 April 2020

\begin{abstract}
Candida albicans remains the most problematic of all Candida species, causing severe infections. Adaptation to different human body niches, such oral and urinary tracts, has been shown to be essential for survival and critical for virulence of $C$. albicans. Thus, the present work aimed to study the behaviour of $C$. albicans on simulated human body fluids (artificial saliva and urine) at different values of $\mathrm{pH}$ ( $\mathrm{pH} 5.8$ and 7) by determining its ability to develop two of the most important virulence factors: biofilms and filamentous forms. Under this study, it was demonstrated that C. albicans was able to grow as free cells and to develop biofilm communities composed of multiple cell types (yeast and elongated hyphal cells) on both simulated human body fluids and under different $\mathrm{pH}$. It was interesting to note that the $\mathrm{pH}$ had little impact on C. albicans planktonic and biofilm growth, despite influencing the development of filamentous shapes in artificial saliva and urine. So, it was possible to infer that $C$. albicans presents a high plasticity and adaptability to different human body fluids, namely saliva and urine. These can be the justification for the high number of oral and urinary candidiasis in the whole world.
\end{abstract}

Keywords: candidiasis; pathogenicity; environmental cues; virulence factor

\section{Introduction}

Yeast species of the genus Candida are responsible for 70-90\% of human fungal infections, with Candida albicans accounting for approximately $40 \%$ of all yeast isolates from clinical samples [1-4]. Infections with $C$. albicans represent an important public health challenge with high economic and medical relevance due to the increased costs of care, time of hospitalisation and high levels of morbidity and mortality, especially in immunocompromised patients [5].

Indeed, C. albicans has been described as able to colonize anatomically distinct sites including the urinary $[6]$ and oral tract $[7,8]$. The pathogenicity of $C$. albicans has been attributed to several virulence factors, such as the ability to evade host defences, adherence, biofilm formation and development of filamentous forms [9-11].

The cell responses to environmental changes, such as $\mathrm{pH}$, allow $\mathrm{C}$. albicans to take advantage of impaired immunity in debilitated patients and therefore facilitate the establishment of candidiasis [12,13]. The diverse niches that $C$. albicans inhabit vary prominently with respect to environmental $\mathrm{pH}$. For instance, the $\mathrm{pH}$ of the oral environment varies significantly resulting from changes in diet, the metabolism of other constituents of the microbiota and salivary flow [14]. In the urinary tract, changes in the amount or type of acid produced are patient-dependent with a urine $\mathrm{pH}$ ranging from 4.5 to 8 [15].

Adaptation to different human body niches, such the oral and urinary tracts, has been shown to be essential for survival and critical for virulence in many commensals' pathogens, namely in 
C. albicans $[16,17]$. Thus, the present work aimed to study the behaviour of $C$. albicans on simulated human body fluids (artificial saliva and urine) at different $\mathrm{pH}$ (5.8 and 7) determining its ability to develop virulence factors, namely, to form biofilms and to develop filamentous forms.

\section{Materials and Methods}

\subsection{Simulated Body Fluids}

To mimic the human body fluids, artificial urine (AU) and saliva (AS), were using during this work. AU (pH 5.8 and 7) and AS (pH 5.8 and 7) were prepared with slight modifications to that described by Silva et al. (2010) and (2013), respectively [18,19]. The composition of AU was $\mathrm{CaCl}_{2}(0.65 \mathrm{~g} / \mathrm{L}), \mathrm{MgCl}_{2}$ $(0.65 \mathrm{~g} / \mathrm{L}), \mathrm{NaCl}(4.6 \mathrm{~g} / \mathrm{L}), \mathrm{Na}_{2} \mathrm{SO}_{4}(2.3 \mathrm{~g} / \mathrm{L}), \mathrm{Na}_{3} \mathrm{C}_{3} \mathrm{H}_{5} \mathrm{O}\left(\mathrm{CO}_{2}\right)_{3}(0.65 \mathrm{~g} / \mathrm{L}), \mathrm{Na}_{2} \mathrm{C}_{2} \mathrm{O}_{4}(0.02 \mathrm{~g} / \mathrm{L}), \mathrm{KH}_{2} \mathrm{PO}_{4}$ $(2.8 \mathrm{~g} / \mathrm{L}), \mathrm{KCl}(1.6 \mathrm{~g} / \mathrm{L}), \mathrm{NH}_{4} \mathrm{Cl}(1.0 \mathrm{~g} / \mathrm{L})$, urea $(25 \mathrm{~g} / \mathrm{L})$, creatinine $(1.1 \mathrm{~g} / \mathrm{L})$, and glucose $(3 \mathrm{~g} / \mathrm{L})$; and the composition of AS was yeast extract $(2 \mathrm{~g} / \mathrm{L})$, peptone $(5 \mathrm{~g} / \mathrm{L})$, glucose $(2 \mathrm{~g} / \mathrm{L})$, mucin $(1 \mathrm{~g} / \mathrm{L}), \mathrm{NaCl}$ $(0.35 \mathrm{~g} / \mathrm{L}), \mathrm{CaCl}_{2}(0.2 \mathrm{~g} / \mathrm{L})$, and $\mathrm{KCl}(0.2 \mathrm{~g} / \mathrm{L})$. The $\mathrm{pH}$ of simulated body fluids was adjusted with a $\mathrm{pH}$ meter (C1010 Benchtop pH Meter, Cleaver Scientific) using hydrochloric acid and/or sodium hydroxide. Roswell Park Memorial Institute (RPMI; Sigma, St Louis, USA) buffered with 3-(N-Morpholino) propanesulfonic acid (MOPS; Sigma-Aldrich, St Louis, MO, USA) and adjusted to $\mathrm{pH} 7$ with sodium hydroxide was used as control of $C$. albicans growth and filamentation in all experiments.

\subsection{Organism and Growth Conditions}

Candida albicans SC5314 strain was used in this study. This strain belongs to the Biofilm group collection, located at the Centre of Biological Engineering of Minho University (Braga, Portugal), and its identity was confirmed by PCR-based sequencing with specific primers (ITS1 and ITS4) [20]. For all experiments, cells were subcultured on sabouraud dextrose agar (SDA; Merck, Germany) and incubated for $24 \mathrm{~h}$ at $37^{\circ} \mathrm{C}$. An inoculum, obtained from SDA plates, was resuspended in sabouraud dextrose broth (SDB; Merck, Germany) and incubated at $37^{\circ} \mathrm{C}$ for $18 \mathrm{~h}$ at $120 \mathrm{rpm}$. After this time, the cells' suspension was centrifuged for $10 \mathrm{~min}$ at $3000 \mathrm{~g}$ and $4{ }^{\circ} \mathrm{C}$ and washed twice with phosphate-buffered saline (PBS; pH 7, 0.1 M). Pellets were resuspended in $5 \mathrm{~mL}$ of PBS and the cellular density adjusted for each experiment using a Neubauer chamber (Marienfild, Land-Konicshofem, Germany) to $1 \times 10^{6}$ cells $\mathrm{mL}^{-1}$.

\subsection{Planktonic Growth Analysis}

\subsubsection{Growth Curves Determination}

For the planktonic growth, a cellular suspension of C. albicans SC5314 prepared in RPMI, AS (pH 5.8 and 7) and $\mathrm{AU}$ (pH 5.8 and 7) were placed in $25 \mathrm{~mL}$ Erlenmeyer flasks and incubated for $30 \mathrm{~h}$ at $37^{\circ} \mathrm{C}$ under agitation in an orbital shaker at $120 \mathrm{rpm}$. The optical density (OD) at $690 \mathrm{~nm}$ was measured over the time using a microtiter plate reader (Thermo Scientific ${ }^{\mathrm{TM}}$ Multiskan ${ }^{\mathrm{TM}} \mathrm{FC}$, Thermo Fisher Scientific, Finland). The specific growth rate was determined for each condition through the linear regression determination obtained from each specific growth performance. All experiments were performed in triplicate and in a minimum of three independent assays.

\subsubsection{Colony Forming Unit (CFU) Quantification}

The number of cultivable cells after $24 \mathrm{~h}$ of planktonic growth was determined by CFUs enumeration [11]. Thus, from each condition $1 \mathrm{~mL}$ of suspension was recovered and the pellets were washed in PBS. Serial dilutions (in PBS) were performed, plated onto SDA and then incubated at $37^{\circ} \mathrm{C}$. The total CFUs per $\mathrm{mL}\left(\log _{10} \mathrm{CFUs} / \mathrm{mL}\right)$ were enumerated after $24 \mathrm{~h}$ of incubation. All experiments were performed in triplicate and in a minimum of three independent assays. 


\subsubsection{Metabolic Activity Determination}

An tetrazolium (XTT) reduction assay was used to determine C. albicans cells metabolic activity [11]. For that, after $24 \mathrm{~h}$ of grown, $1 \mathrm{~mL}$ of each suspension was harvested by centrifugation at $3000 \mathrm{~g}$ at $4{ }^{\circ} \mathrm{C}$ and washed once with PBS. An aliquot of $200 \mu \mathrm{L}$ of a mixture of $100 \mu \mathrm{g} / \mathrm{mL}$ XTT (2,3-(2-methoxy-4-nitro-5-sulphophenyl)-5-[(phenylamino) carbonyl]-2H-tetrazolium hydroxide) (Sigma-Aldrich, USA) and $10 \mu \mathrm{g} / \mathrm{mL}$ PMS (Sigma-Aldrich, USA) was added to each cells pellet and incubated at $37^{\circ} \mathrm{C}$ for $3 \mathrm{~h}$ in the dark at $120 \mathrm{rpm}$. Following this, the OD was measured at $490 \mathrm{~nm}$ using a microtiter plate reader. The metabolic activity was compared for each fluid and the absorbance values were standardized per number of CFUs determined previously, as described in Section 2.3.2 (Abs $490 \mathrm{~nm} / \log _{10}$ CFUs). All experiments were performed in triplicate and in a minimum of three independent assays.

\subsubsection{Filaments Enumeration}

Candida albicans cells were also evaluated in terms of filamentous forms development. For that, at 6, 10 and $24 \mathrm{~h}$, aliquots of each cellular suspension were diluted in PBS and the filaments were counted in an optical microscope using a Neubauer chamber. The results were presented as percentage of filamentous forms. In parallel, the morphology of cells was confirmed through fluorescence microscope (Olympus BX51 coupled with a DP71 digital camera; Olympus, Tokyo, Japan), after staining the cells with $1 \%(v / v)$ of calcofluor (Sigma-Aldrich, EUA) for $15 \mathrm{~min}$ in the dark. The excitation line 405 and the emission filters BA 430-470 (blue channel) were used, and images were acquired with the program FluoView FV100 (Olympus). The length of the filaments was also determined using the ImageJ Plug-in (Maryland, USA) software. All experiments were performed in triplicate and in a minimum of three independent assays.

\subsection{Biofilm Growth Analysis}

\subsubsection{Biofilm Formation}

In order to develop C. albicans biofilms, $1 \mathrm{~mL}$ of cellular suspension $\left(1 \times 10^{6}\right.$ cells $)$, prepared in RPMI, AS and AU was added to 24-well polystyrene microtiter plates (Orange Scientific, Braine$1^{\prime}$ Alleud, Belgium) and incubated at $37^{\circ} \mathrm{C}$ and $120 \mathrm{rpm}$. After 6,10 and $24 \mathrm{~h}$ of incubation, the culture medium was removed and the biofilms were washed twice with PBS to remove the non-adherent cells, and subsequently characterized.

\subsubsection{Biofilm Characterization}

\section{CFUs Quantification}

The number of cultivable cells on biofilms was determined by CFUs counting methodology [11]. Briefly, washed biofilms were scraped from the microtiter wells with $1 \mathrm{~mL}$ of PBS and the suspensions were sonicated for $10 \mathrm{~s}$ at 30\% (Ultrasonic Processor; Cole-Parmer, Illinois, USA) to disaggregate the cells from matrix [11]. Serial decimal dilutions of recovered cells in PBS were plated on SDA and incubated for $24 \mathrm{~h}$ at $37^{\circ} \mathrm{C}$. The results were presented as total of CFUs and the values were standardized per unit area of well $\left(\log _{10} \mathrm{CFUs} \mathrm{cm}{ }^{-2}\right)$. All experiments were performed in triplicate and in a minimum of three independent assays.

\section{Metabolic Activity Determination}

After $24 \mathrm{~h}$ of pre-formed biofilms, they were washed and $200 \mu \mathrm{L}$ of a mixture of XTT and PMS was added at each well and incubated at $37^{\circ} \mathrm{C}$ for $3 \mathrm{~h}$ in dark at $120 \mathrm{rpm}$. It was also added to the control wells (to measure background XTT levels). The evaluation was performed as described previously in Section 2.3.3. The metabolic activity was compared for each fluid and the absorbance values were standardized per values of CFUs (Abs $490 \mathrm{~nm} / \log _{10} \mathrm{CFUs}$ ). The results were presented as previously 
described in Section 2.3.3. All experiments were performed in triplicate and in a minimum of three independent assays.

Total Biomass Quantification

The total biofilm biomass was quantified using a crystal violet (CV) staining methodology [21]. For that, $24 \mathrm{~h}$ pre-formed biofilms were washed and firstly fixed with $500 \mu \mathrm{L}$ of methanol, for $15 \mathrm{~min}$. After the methanol removal, the biofilms were dried at room temperature, and then $500 \mu \mathrm{L}$ of CV ( $1 \%$ $v / v)$ added to each well. The stain was aspirate after $5 \mathrm{~min}$ and its excess was removed by washing the biofilms twice with sterile ultra-pure water. Finally, $500 \mu \mathrm{L}$ of acetic acid $(33 \% v / v)$ was added to each well to release and dissolve the CV stain. The absorbance of the CV solutions was then measured, at $570 \mathrm{~nm}$ and the results presented as absorbance per unit area $\left(\mathrm{Abs} \mathrm{CV} \mathrm{cm}{ }^{-2}\right.$ ). All experiments were performed in triplicate and in a minimum of three independent assays.

Filaments Enumeration

In order to quantify the number of cells in filamentous form state, pre-formed biofilms were scraped from the microtiter plate's wells with PBS and the suspensions were sonicated for $10 \mathrm{~s}$ at $30 \%$ (Ultrasonic Processor; Cole-Parmer, Illinois, USA) to disaggregate the cells from matrix [11]. Then, aliquots of these suspensions were used to determine the percentage of cells as filamentous forms as describe above in Section 2.3.4. All experiments were performed in triplicate and in a minimum of three independent assays.

\subsection{Statistical Analysis}

Data were expressed as the mean \pm standard deviation (SD) of a least three independent experiments. All the results were statistically analyzed using the GraphPad Prism 6 software. All tests were performed with a confidence level of $95 \%$.

\section{Results}

\subsection{Candida albicans Planktonic Growth on Artificial Urine and Saliva}

In order to analyze the ability of $C$. albicans free-cells to grow on simulated human body fluids, the optical density of free-floating cells cultivated in AS (pH 5.8 and 7) and $\mathrm{AU}$ ( $\mathrm{pH} 5.8$ and 7) was monitored for $30 \mathrm{~h}$. Additionally, as a control, C. albicans cells were also grown in RPMI ( $\mathrm{pH} 7$ ). Figure 1a shows that $C$. albicans is able to grow on both simulated human body fluids tested, presenting the expected growth stages. However, the planktonic growth was slightly higher in AS, compared to AU and RPMI. For the same simulated fluid, it was possible to observe that the planktonic growth was slightly different depending on $\mathrm{pH}$. Consistently, the specific growth rate values were higher at $\mathrm{pH} 5.8$ in AS $\left(0.158 \mathrm{~h}^{-1}\right)$ and $\mathrm{AU}\left(0.014 \mathrm{~h}^{-1}\right)$ and lower at $\mathrm{pH} 7$ in AS $\left(0.101 \mathrm{~h}^{-1}\right)$ and $\mathrm{AU}\left(0.007 \mathrm{~h}^{-1}\right)$ (Figure 1a).

Figure $1 \mathrm{~b}$ presents the number of CFUs in the different simulated body fluids after $24 \mathrm{~h}$. Planktonic growth presented higher number of CFUs in AS than in AU, even more than in the biofilms formed in RPMI (pH 7), which was statistically different ( $p$-value $<0.05)$. The metabolic activity of planktonic cells was obtained through the XTT reduction assay and normalized by the number of CFUs obtained (Figure 1c). It was clear that planktonic metabolic activity was dependent on the fluid and on the $\mathrm{pH}$. In fact, $\mathrm{C}$. albicans cells' planktonic growth presented a higher metabolic activity in AS than in AU despite not statistically different ( $p$-value $>0.05$ ). In the case of AS, the metabolic activity was higher than in RPMI, with higher values at $\mathrm{pH} 7$ than in $\mathrm{pH} 5.8$, however without statistical differences. Regarding AU, the metabolic activity was similar for the both $\mathrm{pH}$ tested, however it was slightly lower than RPMI ( $p$-value $>0.05)$. 
(a)

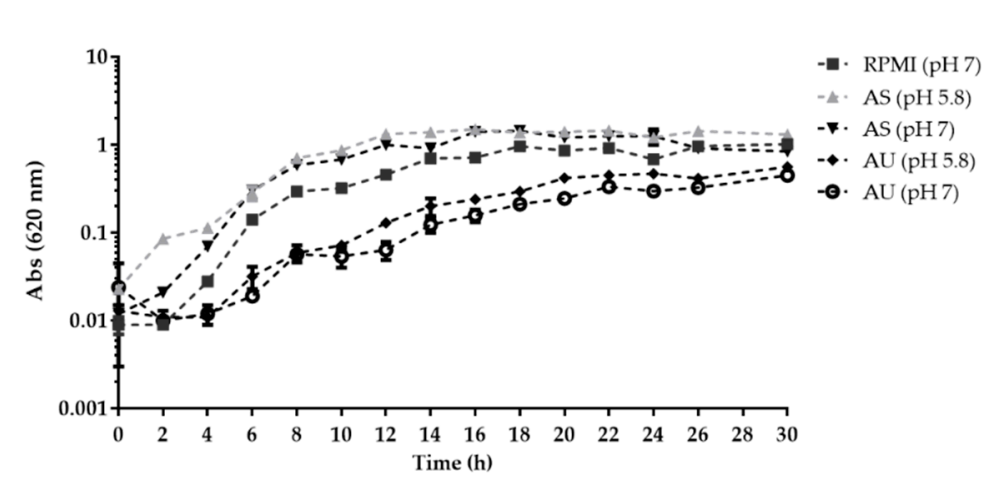

\begin{tabular}{cc}
\hline $\begin{array}{c}\text { Simulated } \\
\text { body fluid }\end{array}$ & $\begin{array}{c}\text { Specific growth } \\
\text { rate }\left(\mathrm{h}^{-1}\right)\end{array}$ \\
\hline RPMI (pH 7) & 0.052 \\
\hline AS (pH 5.8) & 0.158 \\
AS (pH 7) & 0.101 \\
\hline AU (pH 5.8) & 0.014 \\
\hline AU (pH 7) & 0.007 \\
\hline
\end{tabular}

(b)

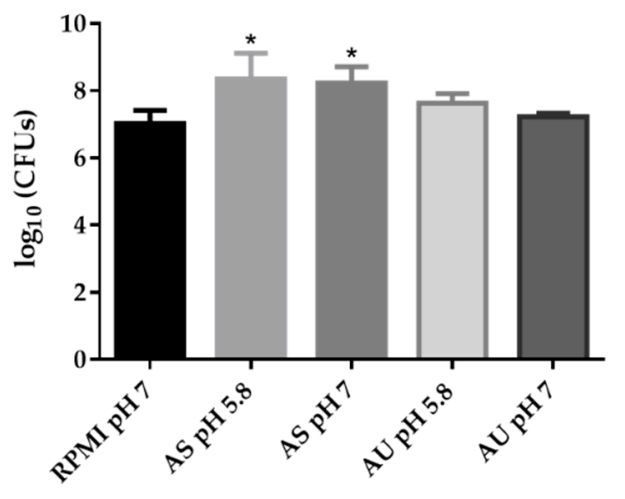

(c)

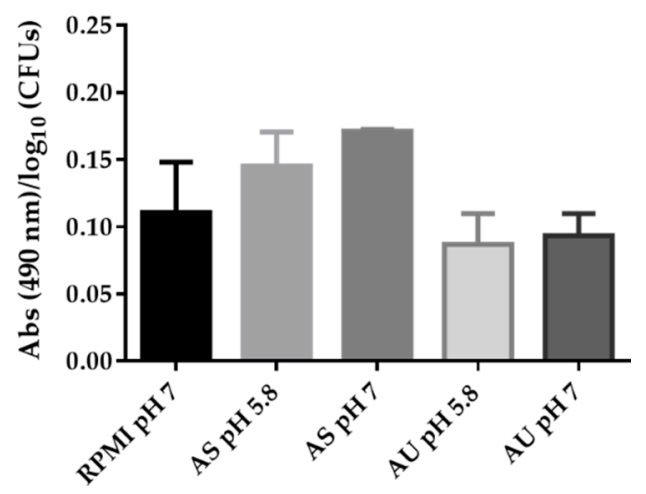

Figure 1. Candida albicans planktonic growth on simulated human body fluids. (a) Growth curves and specific growth rates over $30 \mathrm{~h}$ (b) Number of cultivate cells $\left(\log _{10}\right.$ colony forming units (CFUs) and (c) Metabolic activity determination by XTT reduction (Abs $490 \mathrm{~nm} / \log _{10}$ CFUs) obtained for planktonic growth of C. albicans SC5314 in Roswell Park Memorial Institute (RPMI) pH 7, artificial saliva (AS) (pH 5.8 and $\mathrm{pH} 7$ ) and artificial urine (AU) (pH 5.8 and $\mathrm{pH} 7$ ), at $24 \mathrm{~h}$. Error bars represent standard deviation. * Significant difference between RPMI and simulated fluid ( $p$-value $<0.05$ ).

\subsection{Candida albicans Biofilm Formation on Artificial Urine and Saliva}

In order to determine the ability of $C$. albicans to develop biofilms on simulated body fluids, biofilms were formed in AS ( $\mathrm{pH} 5.8$ and 7) and $\mathrm{AU}$ ( $\mathrm{pH} 5.8$ and 7) over the $24 \mathrm{~h}$. The biofilms were analyzed in terms of number of CFUs (Figure 2a), metabolic activity (Figure 2b) and total biomass (Figure 2c). As in planktonic studies, RPMI ( $\mathrm{pH} 7$ ) medium was used as a control. It was clear, that C. albicans was able to form biofilms in AS and AU at different $\mathrm{pH}$, but the influence of simulated human body fluids on biofilm formation was evident. In fact, C. albicans biofilms presented statistically higher number of cultivable cells in both tested fluids (AS and AU) than in RPMI after 24 h of maturation (Figure 2a) ( $p$-value <0.05).

Figure $2 b$ showed the metabolic activity values of pre-formed biofilms and it was also clear that metabolic activity was dependent on body fluid and $\mathrm{pH}$. It was possible to observe a higher metabolic activity in AS than in AU, even more than in the biofilms formed in RPMI (pH 7) $(p$-value $<0.5)$. Furthermore, biofilms on AS at $\mathrm{pH} 7$ presented metabolic activity values statistically higher than on AS at pH 5.8 and RPMI (pH 7) ( $p$-value < 0.05), which was also observed in the planktonic cell growth (Figure 1c). In contrast, in the case of $\mathrm{AU}$, for both $\mathrm{pH}$, this activity was statistically lower when compared to RPMI ( $\mathrm{pH} 7$ ) ( $p$-value < 0.05). Comparing AU at different $\mathrm{pH}$, a slight decrease of metabolic activity from pH 7 to pH 5.8 ( $p$-value > 0.05) can be seen (Figure 2b). Moreover, comparing both simulated body fluids at the same $\mathrm{pH}$, it was possible to conclude that metabolic activity in AS ( $\mathrm{pH} 5.8$ and $\mathrm{pH} 7$ ) was statistically higher than $\mathrm{AU}(\mathrm{pH} 5.8$ and $\mathrm{pH} 7)$, respectively ( $p$-value $<0.05)$. 
(a)

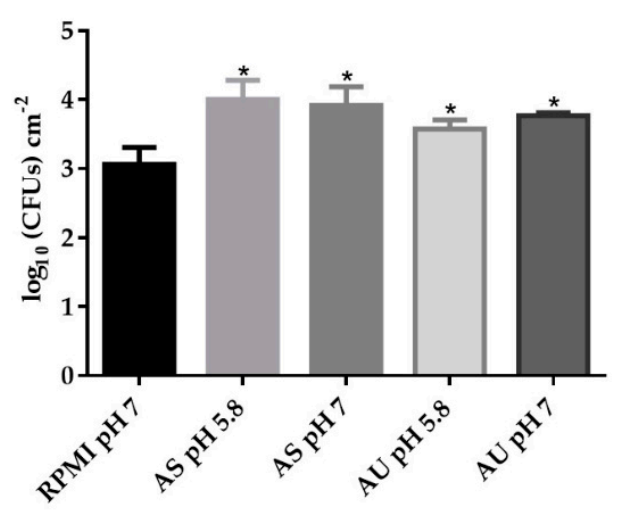

(b)

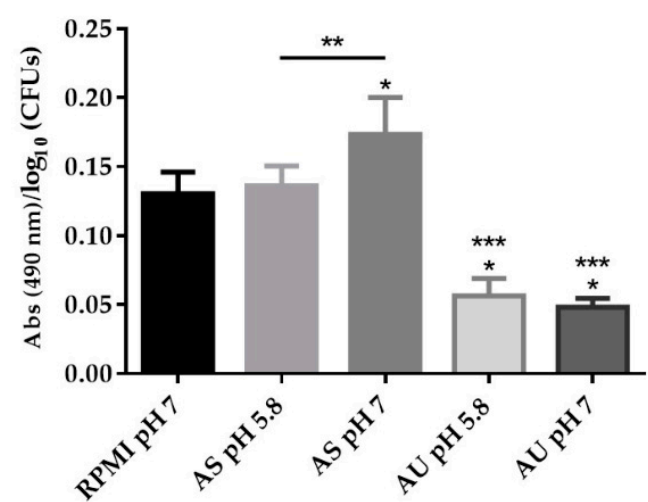

(c)

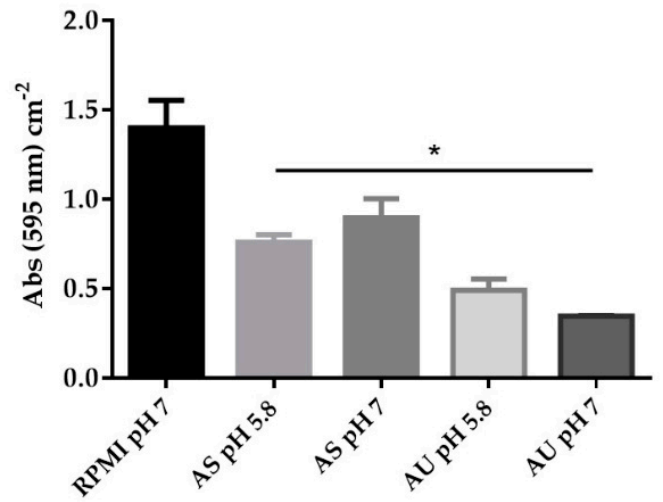

Figure 2. Candida albicans biofilm formation on simulated human body fluids. (a) Cultivate cells enumeration $\left(\log _{10} \mathrm{CFUs} \mathrm{cm}{ }^{-2}\right.$ ); (b) Metabolic activity determination by XTT reduction (Abs $490 \mathrm{~nm} / \log ^{10}$ CFUs) and (c) Total biomass quantification (Absorbance CV cm ${ }^{-2}$ ) of C. albicans SC5314 of formation in RPMI (pH 7), AS (pH 5.8 and 7) and AU (pH 5.8 and 7) developed over 24 h. Error bars represent standard deviation. * Significant differences between RPMI and simulated fluid ( $p$-value $<0.05) ;{ }^{* *}$ Significant differences between $\mathrm{pH}$ at the same body fluid ( $p$-value $\left.<0.05\right)$; ${ }^{* *}$ Significant differences between $\mathrm{AS}$ and $\mathrm{AU}$ for the same $\mathrm{pH}(p$-value $<0.05)$.

Consistently, C. albicans biofilms formed in AS presented higher biomass at $24 \mathrm{~h}$ than on biofilms formed in AU in both $\mathrm{pH}$ (Figure 2c). Moreover, comparing AS at different $\mathrm{pH}$, the total biomass was slightly higher at $\mathrm{pH} 7$ than $\mathrm{pH} 5.8$, and in the case of $\mathrm{AU}$, at $\mathrm{pH} 7$ was slightly lower than $\mathrm{pH}$ 5.8 , however without statistically significant differences between them. The value of total biomass obtained for the biofilms developed in RPMI ( $\mathrm{pH} 7$ ) was statistically superior to the value observed for both simulated human body fluids ( $p$-value $<0.05$ ) (Figure $2 \mathrm{c}$ ).

\subsection{Candida albicans Filamentation on Artificial Urine and Saliva}

Candida albicans cells grown in planktonic and biofilm lifestyles on RPMI (pH 7), AS (pH 5.8 and 7) and $\mathrm{AU}$ (pH 5.8 and 7) were analyzed by optical microscopy in order to evaluate their filamentous forms development (Figure 3). Candida albicans presented a statistically higher percentage of filamentous cells in RPMI ( $\mathrm{pH} 7$ ) in comparison to the percentages observed in AS and AU ( $p$-value $<0.05)$, with exception of AU (pH 5.8) after 6 h of incubation in biofilm lifestyle. In RPMI (pH 7), C. albicans cells reached approximately $100 \%$ of filamentation over $24 \mathrm{~h}$ of grown in both lifestyles, which justifies the highest values on total biomass observed in Figure 2c. The results also revealed that C. albicans cells have a higher ability to develop filamentous forms on AU than in AS. However, in the case of AS, C. albicans presented a greater ability to develop filaments at $\mathrm{pH} 7$ than at $\mathrm{pH} 5.8$, with statistical differences in planktonic cells at $6 \mathrm{~h}$ and $10 \mathrm{~h}$ of incubation ( $p$-value $<0.05$ ) (Figure $3 \mathrm{a})$. In contrast, the 
ability of $C$. albicans to filament in $\mathrm{AU}$ was higher at $\mathrm{pH} 5.8$ compared to $\mathrm{pH} 7$, with statistical differences in planktonic cells for all points and in biofilm cells at $6 \mathrm{~h}$ and $10 \mathrm{~h}$ of incubation ( $p$-value $<0.05$ ). Moreover, comparing the results in same fluid, it was possible to observe a decrease in percentage of C. albicans filaments over the time. In the case of planktonic cells, the percentage of filamentous forms in AS (pH 7) and AU (pH 5.8 and 7) was higher at 6 and $10 \mathrm{~h}$ of incubation than $24 \mathrm{~h}(p$-value $<0.05)$ (Figure 3a). However, in biofilm lifestyle, the number of filaments was higher at $6 \mathrm{~h}$ of incubation than $10 \mathrm{~h}$ and $24 \mathrm{~h}$, except in the case of $\mathrm{AU}(\mathrm{pH} 5.8)$ ( $p$-value < 0.05) (Figure 3b).

(a)

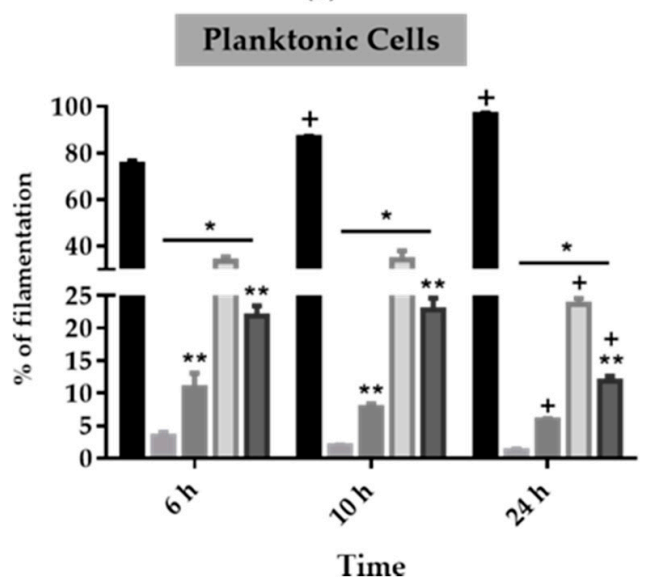

(b)

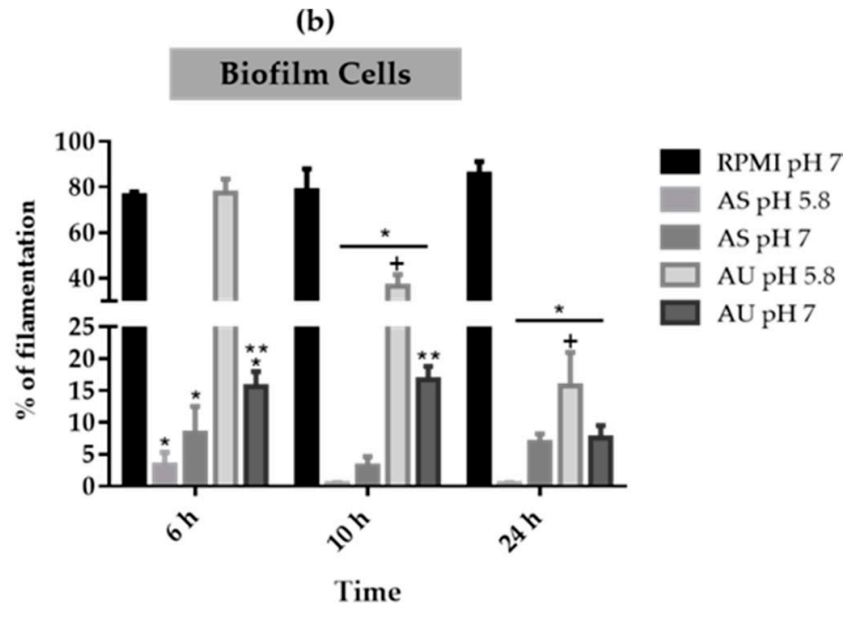

Figure 3. Candida albicans planktonic and biofilms cells filamentation on simulated human body fluids. Filamentous forms percentage of C. albicans SC5314 cells grown in (a) planktonic and (b) biofilm lifestyle in RPMI (pH 7), AS (pH 5.8 and 7) and AU (pH 5.8 and 7) over 24 h. * Significant differences between RPMI and simulated fluids at the same time point $(p$-value $<0.05) ;{ }^{* *}$ Significant differences between $\mathrm{pH}$ at the same body fluid ( $p$-value $<0.05) ;{ }^{+}$Significant differences for the same simulated fluid at different time points $(p$-value $<0.05)$.

The filamentous forms' lengths presented in the different simulated body fluids were determined after fluorescence microscopy observation (Figure 4). It was clear that the filaments' length was much higher in RPMI in both lifestyles compared to simulated body fluids. In other instances, on simulated body fluids the results showed it was verified differences between biofilm and planktonic growth lifestyles in most cases. In the case of AS at both $\mathrm{pH}$, the filaments size on biofilm were much higher (AS pH $5.8(74.37 \pm 34.45 \mu \mathrm{m})$; AS pH $7(126.83 \pm 55.53 \mu \mathrm{m}))$ than in planktonic growth (AS pH 5.8 $(42.76 \pm 19.65 \mu \mathrm{m})$; AS pH $7(33.36 \pm 5.24 \mu \mathrm{m}))$, with more evidence at pH 7 (Figure 4). In contrast, in the case of $\mathrm{AU} \mathrm{pH} \mathrm{5.8,} \mathrm{the} \mathrm{opposite} \mathrm{was} \mathrm{observed,} \mathrm{with} \mathrm{the} \mathrm{planktonic} \mathrm{cells} \mathrm{presenting} \mathrm{a} \mathrm{larger} \mathrm{size}$ $(51.99 \pm 6.22 \mu \mathrm{m})$ compared to biofilm cells $(27.16 \pm 7.42 \mu \mathrm{m})$. Concerning the results of AU pH 7, the filament size was similar between planktonic and biofilm cells (Figure 4). 

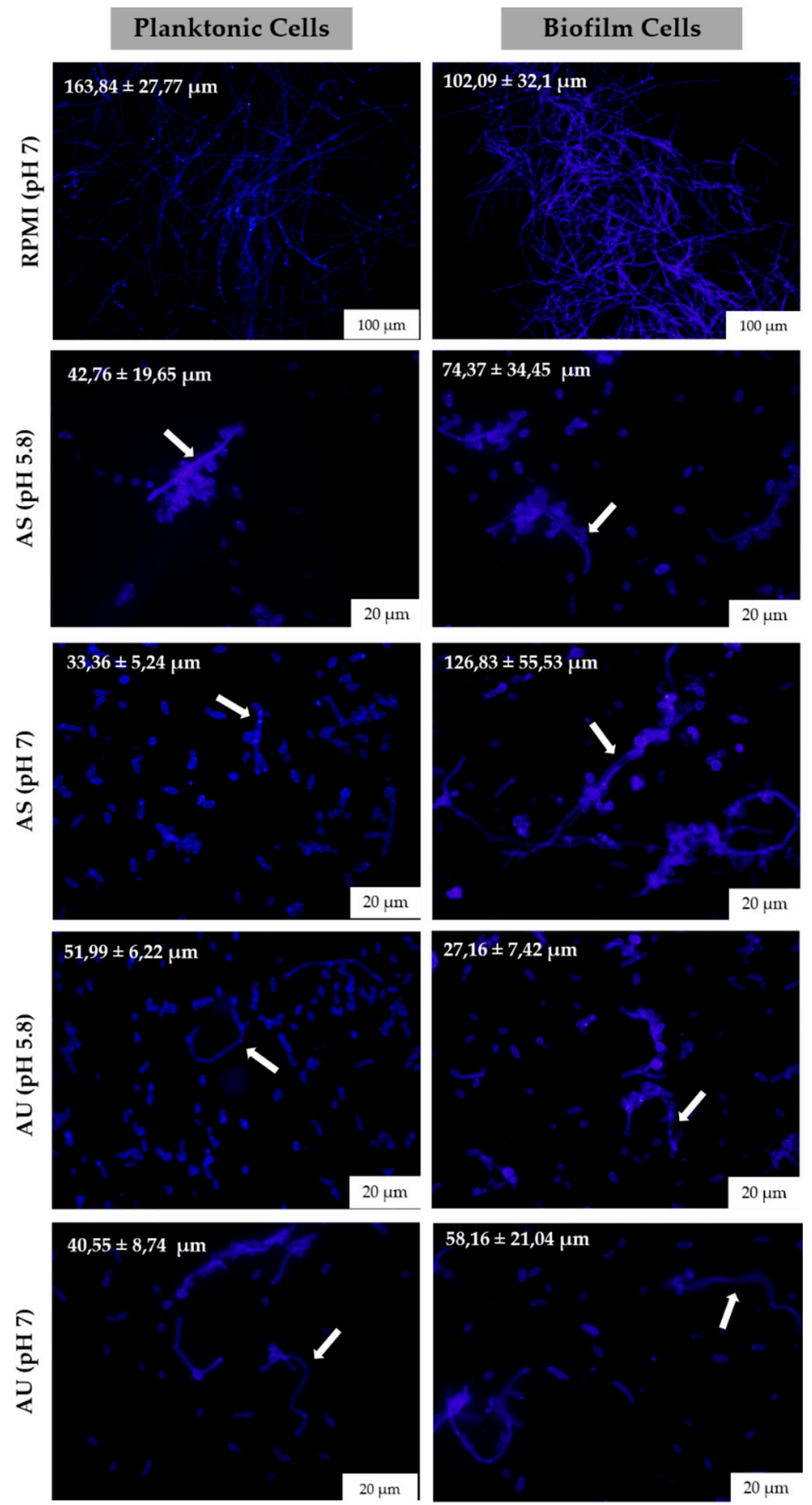

Figure 4. Candida albicans planktonic and biofilms cells filamentation on simulated human body fluids. Fluorescence microscopy images of $C$. albicans SC5314 grown in planktonic and biofilm lifestyle in RPMI (pH 7), AS (pH 5.8 and 7) and AU (pH 5.8 and 7) at $24 \mathrm{~h}$. Original magnification was $10 \times$ for RPMI and $40 \times$ for simulated fluid. Arrows highlight filamentous forms.

\section{Discussion}

Candida albicans remains as the most prevalent of all Candida species with a range of incidence of around $40 \%$ [1,4]. Additionally, C. albicans pathogenicity has been attributed to several virulence factors, such as the ability to evade host defences; adherence; biofilm formation and the development of filamentous forms [11,22]. Candida albicans has been described as able to colonize and infect distinct sites including the urinary and oral tract [6-8]. Several environmental conditions, such as $\mathrm{pH}$, allow C. albicans to take advantage of impaired immunity in immunocompromised patients and 
therefore facilitate the establishment of candidiasis [4,23]. In order to deepen the knowledge about the adaptability of $C$. albicans to different human body niches, the present work aimed to study the ability of $C$. albicans to grow as free cells, to form biofilm communities and to develop filamentous forms on two simulated human body fluids namely saliva and urine at distinct $\mathrm{pH}$ values.

The results revealed that, $C$. albicans is able to grow as free cells in the all fluids tested, however with different growth rates (Figure 1a). Planktonic growth was slightly higher in AS, compared to AU and RPMI. In the case of AS, the planktonic growth of C. albicans was slightly higher at $\mathrm{pH} 5.8$ than $\mathrm{pH}$ 7 and even more than was observed in the control medium (RPMI pH 7). In contrast, the planktonic growth in urine was slower than in the saliva and RPMI and it was observed that at $\mathrm{pH} 5.8$, the growth rate was slightly higher than $\mathrm{pH}$ 7. No correlation was observed between CFUs counts (Figure 1b) and the metabolic activity (Figure 1c) results with a slight increase in values of AS in comparison with AU and RPMI values.

A major virulence attribute of C. albicans is its ability to form biofilms, densely packed communities of cells adhered to a surface $[9,11,22]$. Candida albicans forms are highly structured and composed of multiple cell types (round budding yeast form cells and elongated hyphal cells) encased in an extracellular matrix $[9,22,24,25]$. In Figure 2 , it was possible to observe that $C$. albicans was able to form biofilms on both simulated body fluids at both $\mathrm{pH}$ levels, however with different extensions. It was observed that $C$. albicans formed a stronger biofilm in AS than in AU, with highest metabolic activity (Figure 2b) and total biomass (Figure 2c). As in planktonic growth, no correlation was observed between CFUs number (Figure 2a) and biofilm cells metabolic activity (Figure 2b) at least in the case of AS. Despite C. albicans biofilms had a lower metabolic activity in AS at pH 5.8, these biofilms had a similar number of CFUs when compared to AS at $\mathrm{pH}$ 7. However, in the case of $\mathrm{AU}$, the metabolic activity was similar for both $\mathrm{pH}$, as well as the CFUs. The differences observed between both simulated body fluids can be explained by the presence of different components, such as a higher quantity of glucose in the case of saliva, which promotes the growth of C. albicans as free cells and as biofilm communities [26]. The higher values of glucose on AS may be the justification for the superior ability of C. albicans biofilm formation in this human body fluid (Figure 2). So far, a variety of indirect methods have been described for in vitro biofilms characterization and another important aspect raised by this study is that future research needs to consider which is the most appropriate parameter to investigate in vitro models since total biomass quantification, biofilm activity or cultivable cells do not necessary reflect the behaviour of the biofilm itself.

Besides biofilm formation, the ability to switch from yeast to filamentous forms is becoming one of the most alarming virulence factors associated to C. albicans infections [22]. In order to infer about the ability of C. albicans to filament on simulated body fluids, the numbers of filaments were enumerated in planktonic and biofilm growth lifestyles. Figure 3 reveals that the capability of $C$. albicans to filament was different in the two simulated body fluids. In the case of saliva, C. albicans presented a low rate of filamentation in both lifestyles (Figure 3), however, it showed an increased rate on the length of filaments in biofilm state (Figure 4). In urine, C. albicans cells presented higher numbers of filamentation than in saliva in biofilm lifestyle, despite presenting a decrease over the time. Moreover, in the case of saliva, C. albicans showed more ability to develop filamentous forms at $\mathrm{pH} 7$ than $\mathrm{pH} 5.8$, for both lifestyles. In contrast, in urine, C. albicans showed a higher ability to develop filaments at pH 5.8 than $\mathrm{pH} 7$, in both lifestyles. In fact, it was described that the change of environmental $\mathrm{pH}$ is one of the major challenges often encountered by $C$. albicans making it able to colonize organs in humans with a wide range of $\mathrm{pH}$ conditions $[27,28]$. It has been well investigated that $\mathrm{pH}$ controls yeast in filamentous growth transitions $[27,29,30]$, where acidic $\mathrm{pH}$ represses the yeast in filamentous growth transition, while neutral and alkaline conditions promote filamentation $[27,29]$. These results highlight C. albicans genome plasticity that rapidly generates diversity in response to different environmental human body niches resulting in biofilm formation and/or filaments development, as has been described in other adaptive processes in fungi $[12,13,31,32]$. 


\section{Conclusions}

Infections caused by $C$. albicans are associated with a high mortality and morbidity rate, and their ability to adapt to the different niches of the human body has been shown to be essential for the survival and virulence of these commensals' pathogens. From this study, it was possible to conclude that $C$. albicans presented a high plasticity and adaptability to different human body fluid at different $\mathrm{pH}$ levels, resulting in high ability to grow as free cells or as biofilm communities composed with yeast and elongated hyphal cells. This may be the justification for the high number of the oral and urinary candidiasis in the whole world.

Author Contributions: S.S. and M.H. conceived and designed the study. D.A. and A.B. conducted the experiments and wrote the manuscript. E.R. conducted practical of biofilm experiments. All authors have read and agree to the published version of the manuscript.

Funding: This research received no external funding.

Acknowledgments: This study was supported by the Portuguese Foundation for Science and Technology (FCT) under the scope of the strategic funding of UIDB/04469/2020 unit and BioTecNorte operation (NORTE-01-0145-FEDER-000004) funded by the European Regional Development Fund under the scope of Norte2020—Programa Operacional Regional do Norte and Daniela Eira Araújo PhD grant (SFRH/BD/121417/2016). The authors also acknowledge the project funding by the "02/SAICT/2017-Projetos de Investigação Científica e Desenvolvimento Tecnológico (IC and DT) - POCI-01-0145-FEDER-028893".

Conflicts of Interest: The authors declare no conflict of interest.

\section{References}

1. Horn, D.L.; Neofytos, D.; Anaissie, E.J.; Fishman, J.A.; Steinbach, W.J.; Olyaei, A.J.; Marr, K.A.; Pfaller, M.A.; Chang, C.H.; Webster, K.M. Epidemiology and outcomes of candidemia in 2019 patients: Data from the prospective antifungal therapy alliance registry. Clin. Infect. Dis. 2009, 48, 1695-1703. [CrossRef] [PubMed]

2. Yapar, N. Epidemiology and risk factors for invasive candidiasis. Ther. Clin. Risk Manag. 2014, 10, 95-105. [CrossRef] [PubMed]

3. Gonçalves, B.; Ferreia, C.; Alves, C.T.; Henriques, M.; Azeredo, J.; Silva, S. Vulvovaginal candidiasis: Epidemiology, microbiology and risk factors. Crit. Rev. Microbiol. 2016, 42, 905-927. [CrossRef]

4. Koehler, P.; Stecher, M.; Cornely, O.A.; Koehler, D.; Vehreschild, M.J.G.T.; Bohlius, J.; Wisplinghoff, H.; Vehreschild, J.J. Morbidity and mortality of candidaemia in Europe: An epidemiologic meta-analysis. Clin. Microbiol. Infect. 2019, 25, 1200-1212. [CrossRef] [PubMed]

5. Sardi, J.C.; Scorzoni, L.; Bernardi, T.; Fusco-Almeida, A.M.; Mendes Giannini, M.J. Candida species: Current epidemiology, pathogenicity, biofilm formation, natural antifungal products and new therapeutic options. J. Med. Microbiol. 2013, 62, 10-24. [CrossRef] [PubMed]

6. Behzadi, P.; Behzadi, E.; Ranjbar, R. Urinary tract infections and Candida albicans. Cent. Eur. J. Urol. 2015, 68, 96-101. [CrossRef]

7. Singh, A.; Verma, R.; Murari, A.; Agrawal, A. Oral candidiasis: An overview. J. Oral Maxillofac. Pathol. 2014, $18,81-85$.

8. Williams, D.; Lewis, M. Pathogenesis and treatment of oral candidosis. J. Oral Microbiol. 2011, 3, 1-11. [CrossRef]

9. Mayer, F.L.; Wilson, D.; Hube, B. Candida albicans pathogenicity mechanisms. Virulence 2013, 4, 119-128. [CrossRef]

10. Sawant, B.; Khan, T. Recent advances in delivery of antifungal agents for therapeutic management of candidiasis. Biomed. Pharmacother. 2017, 96, 1478-1490. [CrossRef]

11. Silva, S.; Henriques, M.; Oliveira, R.; Williams, D.; Azeredo, J. In vitro biofilm activity of non-Candida albicans Candida species. Curr. Microbiol. 2010, 61, 534-540. [CrossRef] [PubMed]

12. Pereira, L.; Silva, S.; Ribeiro, B.; Henriques, M.; Azeredo, J. Influence of glucose concentration on the structure and quantity of biofilms formed by Candida parapsilosis. FEMS Yeast Res. 2015, 15, fov043. [CrossRef] [PubMed] 
13. Vylkova, S.; Carman, A.J.; Danhof, H.A.; Collette, J.R.; Zhou, H.; Lorenz, M.C. The fungal pathogen Candida albicans autoinduces hyphal morphogenesis by raising extracellular pH. MBio 2011, 2, e00055-e00111. [CrossRef] [PubMed]

14. Bensen, E.S.; Martin, S.J.; Li, M.; Berman, J.; Davis, D.A. Transcriptional profiling in Candida albicans reveals new adaptive responses to extracellular pH and functions for Rim101p. Mol. Microbiol. 2004, 54, 1335-1351. [CrossRef] [PubMed]

15. Dewar, S.; Reed, L.C.; Koerner, R.J. Emerging clinical role of pivmecillinam in the treatment of urinary tract infection in the context of multidrug-resistant bacteria. J. Antimicrob. Chemother. 2014, 69, 303-308. [CrossRef]

16. Brown, A.J.; Budge, S.; Kaloriti, D.; Tillmann, A.; Jacobsen, M.D.; Yin, Z.; Ene, I.V.; Bohovych, I.; Sandai, D.; Kastora, S.; et al. Stress adaptation in a pathogenic fungus. J. Exp. Biol. 2014, 217, 144-155. [CrossRef]

17. Hall, R.A. Dressed to impress: Impact of environmental adaptation on the Candida albicans cell wall. Mol. Microbiol. 2015, 97, 7-17. [CrossRef]

18. Silva, S.; Negri, M.; Henriques, M.; Oliveira, R.; Williams, D.; Azeredo, J. Silicone colonization by non-Candida albicans Candida species in the presence of urine. J. Med. Microbiol. 2010, 59, 747-754. [CrossRef]

19. Silva, S.; Pires, P.; Monteiro, D.R.; Negri, M.; Gorup, L.F.; Camargo, E.R.; Barbosa, D.B.; Olievira, R.; Williams, D.W.; Henriques, M.; et al. The effect of silver nanoparticles and nystatin on mixed biofilms of Candida glabrata and Candida albicans on acrylic. Med. Mycol. 2013, 51, 178-184. [CrossRef]

20. Williams, D.W.; Wilson, M.J.; Lewis, M.A.; Potts, A.J. Identification of Candida species by PCR and restriction fragment length polymorphism analysis of intergenic spacer regions of ribosomal DNA. J. Clin. Microbiol. 1995, 33, 2476-2479. [CrossRef]

21. Silva, S.; Henriques, M.; Martins, A.; Oliveira, R.; Williams, D.; Azeredo, J. Biofilms of non-Candida albicans Candida species: Quantification, structure and matrix composition. Med. Mycol. 2009, 47, 681-689. [CrossRef] [PubMed]

22. Araújo, D.; Henriques, M.; Silva, S. Portrait of Candida species biofilm regulatory network genes. Trends Microbiol. 2017, 25, 62-75. [CrossRef] [PubMed]

23. Quindós, G. Epidemiology of invasive mycoses: A landscape in continuous change. Rev. Iberoam. Micol. 2018, 35, 171-178. [CrossRef] [PubMed]

24. Casadevall, A.; Pirofski, L. Host-pathogen interactions: The attributes of virulence. J. Infect. Dis. 2001, 184, 337-344. [CrossRef]

25. Saville, S.P.; Lazzell, A.L.; Monteagudo, C.; Lopez-Ribot, J.L. Engineered control of cell morphology in vivo reveals distinct roles for yeast and filamentous forms of Candida albicans during Infection. Eukaryot. Cell. 2003, 2, 1053-1060. [CrossRef]

26. Valentijn-Benz, M.; Nazmi, K.; Brand, H.S.; van't Hof, W.; Veerman, E.C. Growth of Candida albicans in human saliva is supported by low-molecular-mass compounds. FEMS Yeast Res. 2015, 15, 1-8. [CrossRef]

27. Davis, D. Adaptation to environmental $\mathrm{pH}$ in Candida albicans and its relation to pathogenesis. Curr. Genet. 2003, 44, 1-7. [CrossRef]

28. Selvig, K.; Alspaugh, J.A. pH response pathways in fungi: Adapting to host-derived and environmental signals. Mycobiology 2011, 39, 249-256. [CrossRef]

29. Biswas, S.; Van Dijck, P.; Datta, A. Environmental sensing and signal transduction pathways regulating morphopathogenic determinants of Candida albicans. Microbiol. Mol. Biol. Rev. 2007, 71, 348-376. [CrossRef]

30. Huang, G. Regulation of phenotypic transitions in the fungal pathogen Candida albicans. Virulence 2012, 3, 251-261. [CrossRef]

31. Selmecki, A.; Forche, A.; Berman, J. Genomic plasticity of the human fungal pathogen Candida albicans. Eukaryot. Cell. 2010, 9, 991-1008. [CrossRef] [PubMed]

32. Finkel, J.S.; Mitchell, A.P. Genetic control of Candida albicans biofilm development. Nat. Rev. Microbiol. 2011, 9, 109-118. [CrossRef] [PubMed]

(C) 2020 by the authors. Licensee MDPI, Basel, Switzerland. This article is an open access article distributed under the terms and conditions of the Creative Commons Attribution (CC BY) license (http://creativecommons.org/licenses/by/4.0/). 